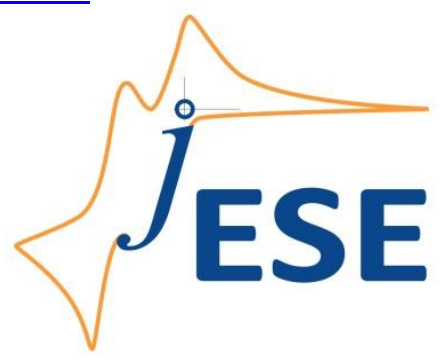

Open Access : : ISSN 1847-9286

www.jESE-online.org

Original scientific paper

\title{
Electrochemical determination of the levels of cadmium, copper and lead in polluted soil and plant samples from mining areas in Zamfara State, Nigeria
}

\author{
Modupe Ogunlesi ${ }^{\boxplus}$, Wesley Okiei, Aderinsola Adio-Adepoju, Michael Oluboyo \\ Chemistry Department, University of Lagos, Akoka, Lagos, Nigeria
}

Corresponding authors E-mail: ${ }^{\square}$ mayogunlesi@yahoo.com; Tel.: +2348033353238

Received: October 10, 2017; Revised: October 18, 2017; Accepted: October 31, 2017

\begin{abstract}
The concentrations of lead, copper and cadmium in soil and plant samples collected from Abare and Dareta villages in Anka local government area of Zamfara State, Nigeria have been electrochemically determined. The study was carried out because of the high mortality of women and children under five, reported for these areas in June 2010. The cause was ascribed to the lead poisoning which has been related to the mining and processing of gold-containing ores. Linear sweep anodic stripping voltammetry technique was used with the glassy carbon working, $\mathrm{Ag} / \mathrm{AgCl}$ reference and platinum auxiliary electrodes. Voltammetric peaks for lead, copper and cadmium that were observed at $495 \mathrm{mV},-19.4 \mathrm{mV}$ and $-675 \mathrm{mV}$, respectively, have formed a basis for construction of the corresponding calibration plots. The concentrations (in $\mathrm{mg} / \mathrm{kg}$ ) of lead, copper and cadmium in the soil samples were found in the ranges of 18.99-26087.70, 2.96-584.60 and 0.00-1354.25, respectively. The concentration values for lead were far above already established USEPA (2002) and WHO (1996) maximum permissible limits for residential areas. The concentrations of lead, copper and cadmium in the food samples ranged between $5.70-79.91,11.17-41.21$ and $0.00-5.74 \mathrm{mg} / \mathrm{kg}$. Several of these values are found well above the FAO/WHO limits of $0.1,2$ and $0.1 \mathrm{mg} / \mathrm{kg}$, respectively. The results indicate that in addition to the lead poisoning, copper and cadmium poisoning may also be responsible for sudden and high mortality in this population.
\end{abstract}

\section{Keywords}

Heavy metals; Mining activities; Soil; Plants; Anodic stripping voltammetry

\section{Introduction}

In June 2010, the Zamfara State Ministry of Health of Nigeria was alerted by Médecins Sans Frontières (MSF) for an increasing number of several deaths and illness among women and children 
under five years in some villages in Bukkuyum and Anka local government area. They contacted the United States Centers for Disease Control (US CDC) who deployed a response team to assist in investigating the outbreak. At the same time, the Blacksmith Institute, USA, sent a team from Terra Graphics Environmental Engineering Inc. to conduct an environmental assessment of the area. These teams worked with the national and state authorities, MSF, and the country office of the World Health Organization (WHO). The investigations confirmed severe lead poisoning in more than 100 children in the villages of Dareta and Yargalma, having a mean blood lead concentration of $119 \mu \mathrm{g} / \mathrm{dL}$. Moreover, soil in and some residential areas in Abare exhibited lead concentrations exceeding 100,000 mg/kg. A random sample of 56 children under 5 years from the villages of Abare and Dareta revealed that over $90 \%$ of them had blood lead concentration $>45 \mu \mathrm{g} / \mathrm{dL}$ and over $70 \%$ had concentrations $>0 \mu \mathrm{g} / \mathrm{dL}[1]$. A high incidence of convulsions and deaths of young children had been recorded in these villages and lead poisoning was implicated. It is generally thought that lead was introduced in the environment by the illegal mining of gold ores.

In the previous study [2], it was reported that our team visited Abare and Dareta villages and observed various processing activities of the ores which could promote metal contamination of the soil, water and vegetables and may constitute health hazards. These include handling the ores with bare hands, eating with unwashed hands, crushing the ores in residential areas, washing the ores in water bodies, exposure of wells to these ores and sometimes drinking polluted water. The concentrations of lead and copper in water from wells, boreholes, ponds and stream from these villages and environs were already reported [2]. Our observations on the research visit to Abare and Dareta villages attributed pollution of soils in the residential areas and farms to the practices of bringing the ores to the residential areas where they are crushed, and irrigating of farmlands by the water already used in processing the ores.

High concentrations of heavy metals in soil would increase potential uptake of these metals by plants and their entering into the food chain [3]. Contamination of food chain becomes increasingly important in a view of its role in human health and nutrition [3-7]. The main threats to human health from heavy metals are associated with exposure to lead, copper, cadmium, mercury and arsenic. These metals may enter the human body through inhalation of dust, consumption of contaminated drinking water and ingestion of food plants grown in contaminated soils [8,9]. The uptake of metals by plants can be affected by several factors which include metal concentrations in soils, soil pH, soil texture, cation exchange capacity, organic matter content of soils as well as the age of the plants [10-12]. Mining activities have been reported to have adverse effects on water resources and farmlands [13] and this could lead to accumulation of heavy metals in plants grown in such contaminated soils.

The aim of this study is to ascertain the level of heavy metal contamination of the soils and plants such as guinea corn and maize seeds in Abare, Dareta and environs, using linear sweep anodic stripping voltammetry technique which offers high sensitivity and rapid response time.

\section{Experimental}

\section{Collection of soil samples}

Soil samples were collected from 30 sites in Abare, Dareta and environs in July 2010. Sampling was done in a ' $W$ ' fashion at sites $10 \mathrm{~m}$ apart. Soil samples were taken at $5 \mathrm{~cm}$ depth. The sampling sites designated DA 01-10 and AB 05-10 were residential areas in Dareta and Abare, where grinding of the ore was carried out. The mining sites in Dareta were designated DA 11-15. The areas around a pond and at the bank of a stream in Abare where the ores were washed are designated AB 01-05 
and $A B 11-15$, respectively. The coordinates of the sampling stations were recorded using a Garmin 38 global positioning system (GPS) device. About $500 \mathrm{~g}$ of each soil sample was collected in polythene bags and labeled. Each sample was then air-dried, sieved (size $2.3 \mathrm{~mm}$ ) and stored in an air tight glass jar.

\section{Collection of plant samples}

Samples of various plants and food items were collected from Abare and Dareta in July 2010. The items which included guinea corn and millet leaves were collected randomly from 50 plants in Dareta. The guinea corn leaves and the millet leaves were each mixed thoroughly before analysis. Elephant grass was obtained from the area of cattle grazing in Abare. Guinea corn and millet seeds were purchased from the homes in Abare and Dareta, while the maize and beans were purchased from the homes in Abare.

\section{Preparation of soil samples}

$1.0 \mathrm{~g}$ of each soil sample was added to $20 \mathrm{~cm}^{3}$ of a mixture of concentrated $\mathrm{HNO}_{3}$ and $\mathrm{H}_{2} \mathrm{O}_{2}$ (30\%) (Sigma-Aldrich) in the ratio $3: 1$. The mixture was heated gradually to $120{ }^{\circ} \mathrm{C}$ and kept at this temperature for 2 hours till a clear solution was obtained. The solution was allowed to cool and filtered into a $50 \mathrm{~cm}^{3}$ standard flask and supplemented with deionized water before transferring to a pre-cleaned plastic bottle.

\section{Preparation of plant samples}

The samples were air-dried in a dust-free environment for three weeks and pulverized using a domestic blender. The digestion of samples was carried out by sequential treatment with $65 \% \mathrm{HNO}_{3}$ and $\mathrm{HClO}_{4}$ (Sigma-Aldrich) according to the method earlier reported [14]. $1 \mathrm{~g}$ of the fine powder of the sample was digested with $20 \mathrm{~cm}^{3}$ of $65 \% \mathrm{HNO}_{3}$ at $80{ }^{\circ} \mathrm{C}$ for one hour. On cooling, $2 \mathrm{~cm}^{3}$ of $70 \%$ $\mathrm{HClO}_{4}$ was added and digested again at $250{ }^{\circ} \mathrm{C}$, until a clear solution was obtained. The mixture was allowed to cool and $20 \mathrm{~cm}^{3}$ of deionized water was added. It was filtered into a $100 \mathrm{~cm}^{3}$ standard flask, supplemented with deionized water and stored in a pre-cleaned plastic container for the heavy metals analysis which was carried out in triplicate within $24 \mathrm{~h}$.

\section{Voltammetric measurements}

A Basi-Epsilon potentiostat/galvanostat was used in the study. The concentrations of heavy metals were determined by linear sweep anodic stripping voltammetry technique $[2,15]$. The working electrode ( $3 \mathrm{~mm}$ diameter) was glassy carbon, while platinum electrode (1.6 mm diameter) served as the auxiliary electrode and $\mathrm{Ag} / \mathrm{AgCl}$ as the reference electrode. The working electrode was polished with alumina powder to obtain a mirror-like image, washed with de-ionized water and placed in a pyranha solution for $2 \mathrm{~min}$, washed with de-ionized water and dried.

\section{Calibration curve}

Standard solution of each metal was prepared by dissolving the weighed amount of the salt $\left(0.1598 \mathrm{~g}\right.$ of $\left.\mathrm{Pb}\left(\mathrm{NO}_{3}\right)_{2}\right),\left(0.3929 \mathrm{~g}\right.$ of $\left.\mathrm{CuSO}_{4} \times 5 \mathrm{H}_{2} \mathrm{O}\right)$ and $0.2745 \mathrm{~g}$ of $\mathrm{Cd}\left(\mathrm{NO}_{3}\right)_{2} \times 4 \mathrm{H}_{2} \mathrm{O}$ ), (all from SigmaAldrich) in $100 \mathrm{~cm}^{3}$ of deionized water to give 1000 ppm of lead, copper and cadmium, respectively. From these solutions, serial dilutions were made with $0.1 \mathrm{M}$ acetate buffer, pH 4.50 containing 80 ppm $\mathrm{Hg}\left(\mathrm{NO}_{3}\right)_{2}$ and $0.2 \mathrm{M} \mathrm{KNO}_{3}$ to give the working concentrations of 250, 500, 1000, 2000 and $2500 \mathrm{ppb}$ of each metal. These diluted solutions were used to obtain the calibration curves. For this purpose, $10 \mathrm{~cm}^{3}$ of each of the standard solution of the metal was transferred into the electrochemical cell and purged with nitrogen for $10 \mathrm{~min}$. The pre-concentration of the metal was 
carried out at $-900 \mathrm{mV}$ for $120 \mathrm{~s}$ with stirring and after a quiet time of $30 \mathrm{~s}$, the stripping process was carried out by scanning the potential from $-900 \mathrm{mV}$ to $200 \mathrm{mV}$ at the scan rate of $20 \mathrm{mV} / \mathrm{s}$. Peak currents for lead, copper and cadmium were observed at $-495 \mathrm{mV},-19.4 \mathrm{mV}$ and $-675 \mathrm{mV}$, respectively. These peak current values were used to construct the calibration plots for determination of the concentrations of $\mathrm{Pb}, \mathrm{Cu}$ and $\mathrm{Cd}$.

Analysis of samples

$5 \mathrm{~cm}^{3}$ of each digested soil or plant sample was transferred into the electrochemical cell and $5 \mathrm{~cm}^{3}$ of $0.2 \mathrm{M}$ acetate buffer, $\mathrm{pH} 4.50$, containing $160 \mathrm{ppm} \mathrm{Hg}\left(\mathrm{NO}_{3}\right)_{2}$ and $0.2 \mathrm{M} \mathrm{KNO}_{3}$ was added and mixed thoroughly. The solution was purged with nitrogen for $10 \mathrm{~min}$ and the potential scanned as described for the standard solutions. The values of the peak current obtained at $-495 \mathrm{mV}$, 19.4 $\mathrm{mV}$ and $-675 \mathrm{mV}$ were used to determine the concentrations of $\mathrm{Pb}, \mathrm{Cu}$ and $\mathrm{Cd}$ in the samples.

\section{Results}

Similarly to already described determinations of calibration plots for $\mathrm{Pb}$ and $\mathrm{Cu}$ [2], Figure 1 shows the overlay of voltammograms of standard solutions of $\mathrm{Cd}$, while Figure 2 shows the calibration plot for Cd in the concentration range of 250-2000 ppb.

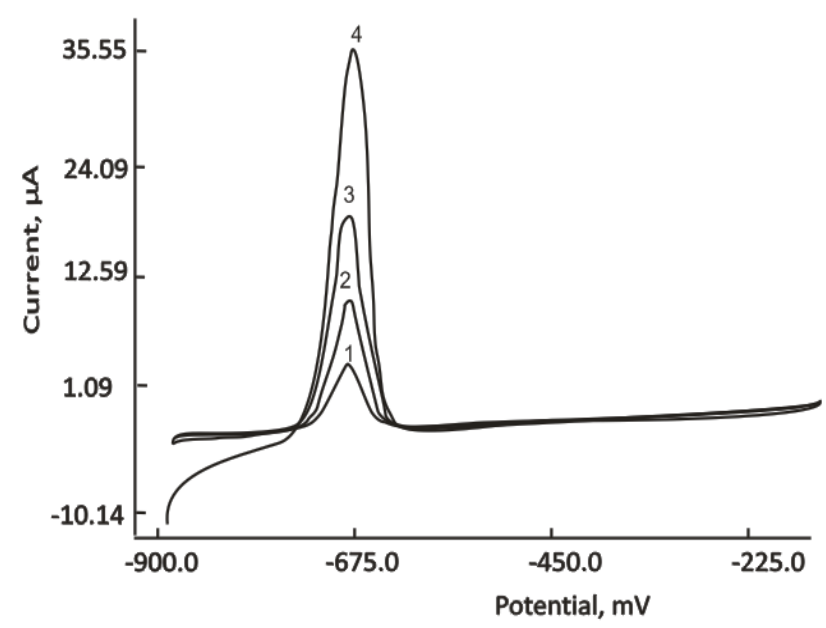

Fig. 1. Overlay of the voltammograms obtained for standard solutions of $\mathrm{Cd}\left(\mathrm{NO}_{3}\right)_{2} \times 4 \mathrm{H}_{2} \mathrm{O}$ in $0.1 \mathrm{M}$ acetate buffer, $\mathrm{pH} 4.5$ containing $80 \mathrm{ppm}$ $\mathrm{Hg}\left(\mathrm{NO}_{3}\right)_{2}$ and $0.2 \mathrm{M} \mathrm{KNO}_{3}$. Cd concentration: 250 ppb (1), 500 ppb (2), 1000 ppb (3), 2000 ppb (4).

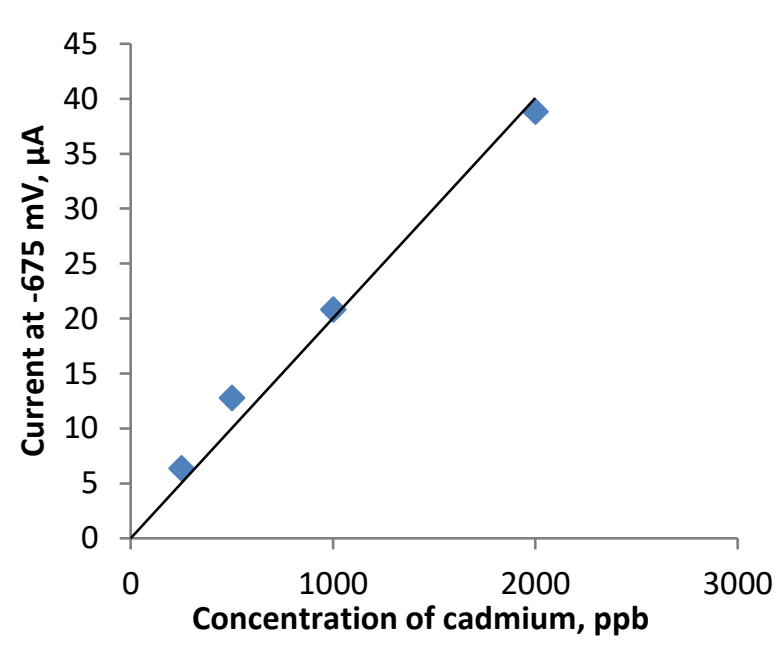

Fig. 2. Calibration plot of peak currents at $-675 \mathrm{mV}$ against $\mathrm{Cd}$ concentration in $0.1 \mathrm{M}$ acetate buffer $\mathrm{pH} 4.50$, containing $80 \mathrm{ppm} \mathrm{Hg}\left(\mathrm{NO}_{3}\right)_{2}$ and $0.2 \mathrm{M} \mathrm{KNO}_{3}$.

The voltammograms obtained for the determination of metals in soil samples $A B 04$ and $A B 13$ are shown in Figures 3 and 4, respectively.

Figures 5 and 6 show voltammograms for the determination of $\mathrm{Pb}, \mathrm{Cu}$ and $\mathrm{Cd}$ in millet leaves and guinea corn from Dareta.

The results showing the concentrations of $\mathrm{Cu}, \mathrm{Cd}$ and $\mathrm{Pb}$ in soils from the various sampling sites are presented in Table 1, while the corresponding results for the plants are listed in Table 2. 


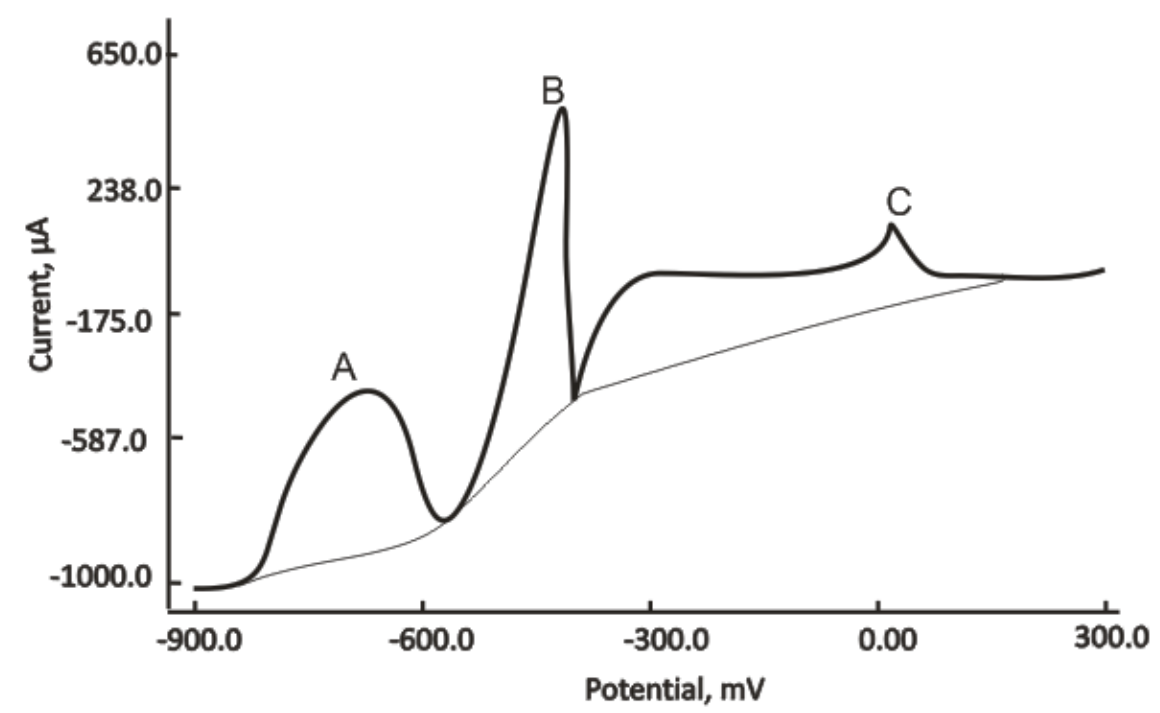

Fig. 3. Voltammograms of the soil sample from Abare $A B 04$ in $0.1 \mathrm{M}$ acetate buffer, $\mathrm{pH} 4.5$ containing 80 ppm $\mathrm{Hg}\left(\mathrm{NO}_{3}\right)_{2}$ and $0.2 \mathrm{M} \mathrm{KNO}_{3}$. Peaks $\mathrm{A}, \mathrm{B}$ and $\mathrm{C}$ correspond to $\mathrm{Cd}, \mathrm{Pb}$ and Cu respectively.

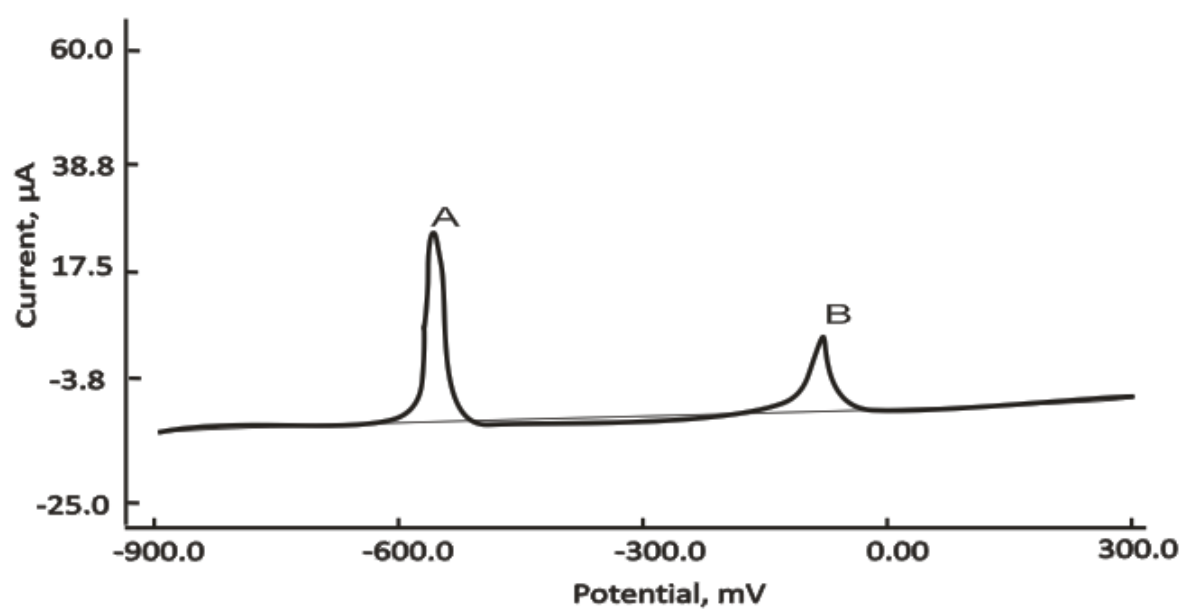

Fig. 4. Voltammogram of the soil sample from Abare, $A B 13$ in $0.1 \mathrm{M}$ acetate buffer, $p H 4.5$ containing $80 \mathrm{ppm} \mathrm{Hg}\left(\mathrm{NO}_{3}\right)_{2}$ and $0.2 \mathrm{M} \mathrm{KNO}_{3}$. Peaks $\mathrm{A}$ and $\mathrm{B}$ correspond to $\mathrm{Pb}$ and $\mathrm{Cu}$, respectively.

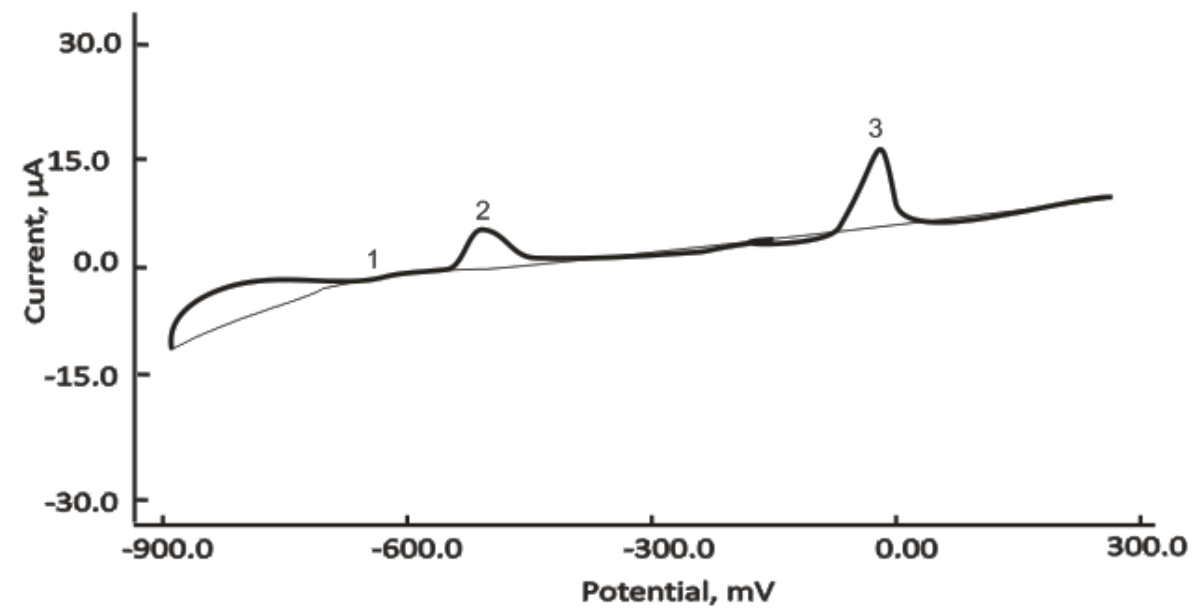

Fig 5. Voltammogram of millet leaves from Dareta in $0.1 \mathrm{M}$ acetate buffer, $\mathrm{pH} 4.5$, containing $80 \mathrm{ppm} \mathrm{Hg}\left(\mathrm{NO}_{3}\right)_{2}$ and $0.2 \mathrm{M} \mathrm{KNO}_{3}$. Peaks 1, 2, and 3 correspond to $\mathrm{Cd} \mathrm{Pb}$ and $\mathrm{Cu}$ 


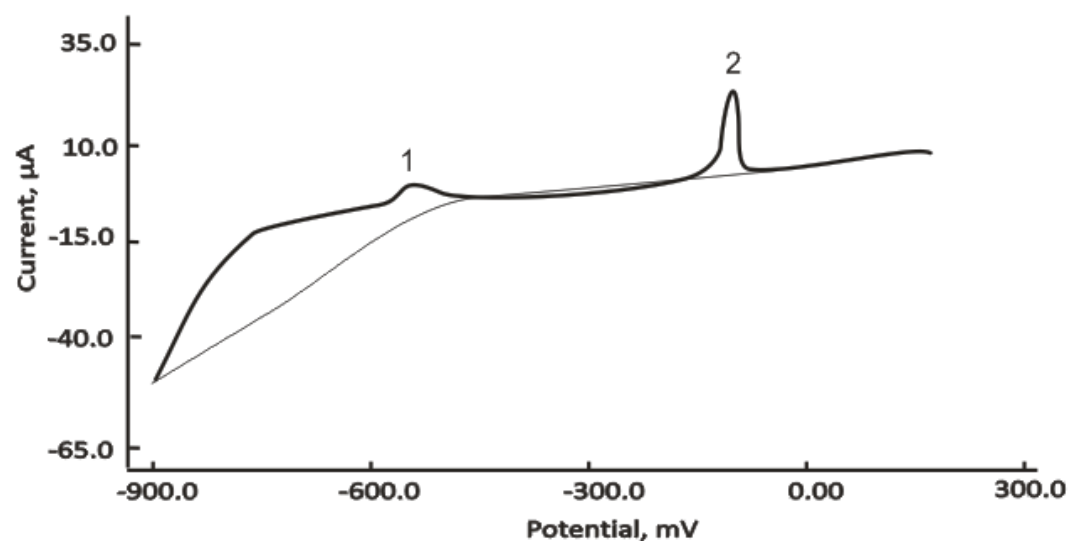

Fig. 6. Voltammogram of guinea corn seed from Dareta in $0.1 \mathrm{M}$ acetate buffer $\mathrm{pH} 4.5$, containing $80 \mathrm{ppm}$ $\mathrm{Hg}\left(\mathrm{NO}_{3}\right)_{2}$ and $0.2 \mathrm{M} \mathrm{KNO}_{3}$. Peaks 1 and 2 correspond to $\mathrm{Pb}(-495 \mathrm{mV})$ and $\mathrm{Cu}(-19.4 \mathrm{mV})$

Table 1. Concentrations of $\mathrm{Pb}, \mathrm{Cu}$ and $\mathrm{Cd}$ in soil samples from Dareta and Abare villages in Zamfara State

\begin{tabular}{|c|c|c|c|c|}
\hline Soil sample & Coordinate & Content of $\mathrm{Pb}, \mathrm{mg} / \mathrm{kg}$ & Content of $\mathrm{Cu} \mathrm{mg} / \mathrm{kg}$ & Content of $\mathrm{Cd}, \mathrm{mg} / \mathrm{kg}$ \\
\hline DA 01 (Grinding site) & $\begin{array}{l}\text { N } 12^{\circ} 01^{\prime} 50.2^{\prime \prime} \\
\text { E } 005^{\circ} 57^{\prime} 30.5^{\prime \prime}\end{array}$ & $1175.00 \pm 8.40$ & $36.604 \pm 6.00$ & ND \\
\hline DA 02(Grinding site) & $\begin{array}{l}\text { N } 12^{0} 01^{\prime} 42.6^{\prime \prime} \\
\text { E } 005^{\circ} 57^{\prime} 18.7^{\prime \prime}\end{array}$ & $40.04 \pm 1.10$ & $2.96 \pm 0.28$ & ND \\
\hline DA 03(Grinding site) & $\begin{array}{l}\text { N } 12^{\circ} 01^{\prime} 41.6^{\prime \prime} \\
\text { E } 005^{\circ} 57^{\prime} 18.7^{\prime \prime}\end{array}$ & $36.16 \pm 0.18$ & $10.86 \pm 1.80$ & ND \\
\hline DA 04(Grinding site) & $\begin{array}{l}N 12^{\circ} 01^{\prime} 29.6^{\prime \prime} \\
\text { E } 05^{\circ} 57^{\prime} 44.0^{\prime \prime}\end{array}$ & $18.99 \pm 0.70$ & $32.84 \pm 0.50$ & ND \\
\hline DA 05(Grinding site) & $\begin{array}{l}\text { N } 12^{\circ} 01^{\prime} 39.5^{\prime \prime} \\
\text { E } 005^{\circ} 57^{\prime} 32.1^{\prime \prime}\end{array}$ & $21.06 \pm 0.24$ & $6.56 \pm 0.11$ & ND \\
\hline DA 06(Grinding site) & $\begin{array}{l}\text { N } 12^{\circ} 01^{\prime} 51.8^{\prime \prime} \\
\text { E } 005^{\circ} 57^{\prime} 21.3^{\prime \prime}\end{array}$ & $26087.70 \pm 16.20$ & $78.51 \pm 1.66$ & ND \\
\hline DA 07(Grinding site) & $\begin{array}{l}N 12^{\circ} 01^{\prime} 51.7^{\prime \prime} \\
\text { E } 005^{\circ} 57^{\prime} 21.2^{\prime \prime}\end{array}$ & $438.56 \pm 2.20$ & $9.73 \pm 1.27$ & ND \\
\hline DA 08(Grinding site) & $\begin{array}{l}\text { N } 12^{\circ} 01^{\prime} 52.0^{\prime \prime} \\
\text { E } 005^{\circ} 57^{\prime} 20.9^{\prime \prime}\end{array}$ & $438.56 \pm 1.30$ & $9.73 \pm 0.54$ & ND \\
\hline DA 09(Grinding site) & $\begin{array}{l}\text { N } 12^{0} 01^{\prime} 51.7^{\prime \prime} \\
\text { E } 005^{\circ} 57^{\prime} 21.2^{\prime \prime}\end{array}$ & $701.30 \pm 0.91$ & $33.26 \pm 1.20$ & ND \\
\hline DA 10 (Grinding site) & $\begin{array}{l}\text { N } 12^{\circ} 01^{\prime} 51.8^{\prime \prime} \\
\text { E } 005^{\circ} 57^{\prime} 21.0^{\prime \prime}\end{array}$ & $339.46 \pm 1.10$ & $38.69 \pm 1.10$ & ND \\
\hline DA 11 (Mining site) & $\begin{array}{l}\text { N } 12^{\circ} 01^{\prime} 15.8^{\prime \prime} \\
\text { E } 005^{\circ} 57^{\prime} 34.0^{\prime \prime}\end{array}$ & $1128.51 \pm 26$ & $123.08 \pm 2.91$ & $804.50 \pm 5.60$ \\
\hline DA 12 (Mining site) & $\begin{array}{l}\text { N } 12^{\circ} 01^{\prime} 15.3^{\prime \prime} \\
\text { E } 005^{\circ} 57^{\prime} 34.3^{\prime}\end{array}$ & $630.70 \pm 1.22$ & $54.30 \pm 1.80$ & ND \\
\hline DA 13(Mining site) & $\begin{array}{l}\mathrm{N} 12^{\circ} 01^{\prime} 15.0^{\prime \prime} \\
\text { E } 005^{\circ} 57^{\prime} 34.0^{\prime \prime}\end{array}$ & $167.54 \pm 1.00$ & $54.30 \pm 1.40$ & ND \\
\hline DA 14(Mining site) & $\begin{array}{l}\text { N } 12^{\circ} 01^{\prime} 14.7^{\prime \prime} \\
\text { E } 005^{\circ} 57^{\prime} 34.0^{\prime \prime}\end{array}$ & $3760.96 \pm 4.1$ & $213.80 \pm 2.80$ & $1354.25 \pm 7.50$ \\
\hline DA 15(Mining site) & $\begin{array}{l}\text { N } 12^{\circ} 01^{\prime} 14.9^{\prime \prime} \\
\text { E } 005^{\circ} 57^{\prime} 34.2^{\prime \prime}\end{array}$ & $481.14 \pm 6.50$ & $48.64 \pm 1.80$ & ND \\
\hline AB 01(Washing site) & $\begin{array}{l}\text { N } 12^{\circ} 04^{\prime} 41.2^{\prime \prime} \\
\text { E } 005^{\circ} 57^{\prime} 29.1^{\prime \prime}\end{array}$ & $900.40 \pm 1.30$ & $92.53 \pm 3.50$ & ND \\
\hline AB 02(Washing site) & $\begin{array}{l}\mathrm{N} 12^{\circ} 04^{\prime} 42.1^{\prime \prime} \\
\mathrm{E} 005^{\circ} 57^{\prime} 30.6^{\prime \prime}\end{array}$ & $4051.76 \pm 28$ & $458.37 \pm 1.50$ & ND \\
\hline AB 03(Washing site) & $\begin{array}{l}\text { N } 12^{\circ} 04^{\prime} 41.5^{\prime \prime} \\
\text { E } 005^{\circ} 57^{\prime} 29.0^{\prime \prime}\end{array}$ & $606.14 \pm 2.80$ & $33.71 \pm 2.50$ & ND \\
\hline AB 04(Washing site) & $\begin{array}{l}\text { N } 12^{\circ} 04^{\prime} 41.2^{\prime \prime} \\
\text { E } 005^{\circ} 57^{\prime} 29.7^{\prime \prime}\end{array}$ & $3720.62 \pm 3.00$ & $584.60 \pm 2.85$ & $1216.25 \pm 9.50$ \\
\hline AB 05(Washing site) & $\begin{array}{l}\text { N } 12^{0} 04^{\prime} 40.6^{\prime \prime} \\
\text { E } 005^{\circ} 57^{\prime} 29.2^{\prime \prime}\end{array}$ & $390.79 \pm 5.10$ & $50.91 \pm 3.50$ & ND \\
\hline AB 06(Grinding site) & $\begin{array}{l}\text { N } 12^{\circ} 04^{\prime} 41.3^{\prime \prime \prime} \\
\text { E } 005^{\circ} 57^{\prime} 26.2^{\prime \prime}\end{array}$ & $38.16 \pm 0.87$ & $15.16 \pm 1.25$ & ND \\
\hline AB 07(Grinding site) & $\begin{array}{l}\text { N } 12^{\circ} 04^{\prime} 40.7^{\prime \prime} \\
\text { E } 005^{\circ} 57^{\prime} 26.2^{\prime \prime}\end{array}$ & $489.48 \pm 1.80$ & $17.19 \pm 0.68$ & ND \\
\hline
\end{tabular}




\begin{tabular}{|c|c|c|c|c|}
\hline Soil sample & Coordinate & Content of $\mathrm{Pb}, \mathrm{mg} / \mathrm{kg}$ & Content of $\mathrm{Cu} \mathrm{mg} / \mathrm{kg}$ & Content of $\mathrm{Cd}, \mathrm{mg} / \mathrm{kg}$ \\
\hline AB 08(Grinding site) & 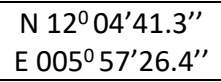 & $111.899 \pm 2.10$ & $24.35 \pm 1.35$ & ND \\
\hline AB 09(Grinding site) & $\begin{array}{l}\text { N } 12^{0} 04^{\prime} 40.7^{\prime \prime} \\
\text { E } 005^{\circ} 57^{\prime} 26.8^{\prime \prime}\end{array}$ & $1615.79 \pm 3.20$ & $49.10 \pm 3.50$ & ND \\
\hline AB 10 (Grinding site) & $\begin{array}{l}\text { N } 12^{0} 04^{\prime} 41.3^{\prime \prime} \\
\text { E } 005^{\circ} 57^{\prime} 27.0^{\prime \prime}\end{array}$ & $207.89 \pm 1.85$ & $10.86 \pm 1.67$ & ND \\
\hline AB 11(Washing site) & $\begin{array}{l}\text { N } 12^{\circ} 04^{\prime} 22.7^{\prime \prime} \\
\text { E } 005^{\circ} 57^{\prime} 28.3^{\prime \prime}\end{array}$ & $287.54 \pm 0.87$ & $92.69 \pm 2.50$ & $8.03 \pm 1.35$ \\
\hline AB 12(Washing site) & $\begin{array}{l}\text { N } 12^{\circ} 04^{\prime} 21.7^{\prime \prime} \\
\text { E } 005^{\circ} 57^{\prime} 27.6^{\prime \prime}\end{array}$ & $1323.68 \pm 4.51$ & $204.52 \pm 3.45$ & ND \\
\hline AB 13(Washing site) & $\begin{array}{l}\text { N } 12^{0} 04^{\prime} 23.1^{\prime \prime} \\
\text { E } 005^{\circ} 57^{\prime} 28.8^{\prime \prime}\end{array}$ & $205.56 \pm 1.25$ & $40.04 \pm 2.31$ & ND \\
\hline $\begin{array}{l}\text { AB 14(Processing } \\
\text { site) }\end{array}$ & $\begin{array}{l}\text { N } 12^{\circ} 04^{\prime} 22.9^{\prime \prime} \\
\text { E } 005^{\circ} 57^{\prime} 29.3^{\prime \prime}\end{array}$ & $390.79 \pm 3.10$ & $69.91 \pm 1.40$ & ND \\
\hline AB 15(Washing site) & $\begin{array}{l}\text { N } 12^{0} 04^{\prime} 23.1^{\prime \prime} \\
\text { E } 005^{\circ} 57^{\prime} 29.5^{\prime \prime}\end{array}$ & $51.586 \pm 1.20$ & $23.55 \pm 1.48$ & ND \\
\hline
\end{tabular}

ND: Not detected.

Table 2. Concentrations of metals in samples of plants and food from Abare and Dareta, Zamfara State.

\begin{tabular}{ccccc}
\hline Plant/food SAMPLE & LOCATION & $\begin{array}{c}\text { Content of Pb, } \\
\mathbf{m g} / \mathbf{k g}\end{array}$ & $\begin{array}{c}\text { Content of } \mathbf{C u} \\
\mathbf{m g} / \mathbf{k g}\end{array}$ & $\begin{array}{c}\text { Content of Cd, } \\
\mathbf{m g} / \mathbf{k g}\end{array}$ \\
\hline Elephant grass & Abare & $24.63 \pm 0.05$ & $27.37 \pm 0.08$ & $\mathrm{ND}$ \\
\hline Guinea Corn seeds & Abare & $15.60 \pm 0.15$ & $11.17 \pm 0.07$ & $\mathrm{ND}$ \\
\hline Maize & Abare & $24.56 \pm 0.04$ & $12.72 \pm 0.06$ & $5.74 \pm 0.13$ \\
\hline Beans & Abare & $10.64 \pm 0.05$ & $30.41 \pm 0.10$ & $\mathrm{ND}$ \\
\hline Millet seeds & Abare & $5.70 \pm 0.06$ & $14.84 \pm 0.06$ & $\mathrm{ND}$ \\
\hline Guinea corn seeds & Dareta & $79.91 \pm 0.07$ & $41.21 \pm 0.05$ & $\mathrm{ND}$ \\
\hline Guinea corn leaves & Dareta & $36.86 \pm 0.10$ & $19.05 \pm 0.03$ & $\mathrm{ND}$ \\
\hline Millet seeds & Dareta & $22.29 \pm 0.09$ & $11.53 \pm 0.10$ & $\mathrm{ND}$ \\
\hline Millet leaves & Dareta & $22.76 \pm 0.09$ & $40.58 \pm 0.20$ & $5.34 \pm 0.08$ \\
\hline FAO/WHO (2011) & -- & 0.1 & 2 & 0.1 \\
\hline
\end{tabular}

ND: Not Detected

\section{Discussion}

\section{Soil analysis}

The concentration levels of $\mathrm{Pb}, \mathrm{Cu}$ and $\mathrm{Cd}$ in soil samples listed in Table 1 can be considered based on the processes carried out at each specific location. DA 01-10 are residences where grinding of ores is carried out by women and children. DA 11-15 denote the mining sites located $3.5 \mathrm{~km}$ from Dareta. Sites AB 01-05 are located around a pond in Abare. Sites AB 06-10 are grinding areas located in residences in Abare, while $A B$ 11-15 are sites located by the stream in Abare where the processors wash the powdered ores to obtain gold.

Data in Table 1 show that in the residential areas in Dareta (DA 01-DA 10), concentrations of Pb were detected in the range $18.99-26087.70 \mathrm{mg} / \mathrm{kg}$, Cu was detected in the range $2.96-78.51 \mathrm{mg} / \mathrm{kg}$, while $\mathrm{Cd}$ was not detected at all. At the mining sites in Dareta (DA 11-DA 15), the levels of Pb and $\mathrm{Cu}$ were in the range $167.54-3760.96 \mathrm{mg} / \mathrm{kg}$ and $48.64-123.08 \mathrm{mg} / \mathrm{kg}$, respectively. Cadmium was found at two mining locations in Dareta (DA 11 and DA 14) in concentrations of $804.50 \mathrm{mg} / \mathrm{kg}$ and $1354.25 \mathrm{mg} / \mathrm{kg}$, respectively. At the pond environ sites in Abare ( $A B$ 01-AB 05), the levels for $\mathrm{Pb}$ and $\mathrm{Cu}$ were in the range $390.79-4051.76 \mathrm{mg} / \mathrm{kg}$ and $33.71-584.60 \mathrm{mg} / \mathrm{kg}$, respectively, while Cd was found at one site ( $A B$ 04) in the concentration of $1216.25 \mathrm{mg} / \mathrm{kg}$. The levels of $\mathrm{Pb}$ and $\mathrm{Cu}$ at grinding 
sites of residential areas in Abare (AB 06-AB 10) were detected in the range of 38.16-1615.79 mg/kg and $10.86-49.10 \mathrm{mg} / \mathrm{kg}$, respectively. Cadmium was not detected in these samples. At the ore washing sites in Abare (AB 11-AB 15) at the bank of a stream, the levels of $\mathrm{Pb}$ and $\mathrm{Cu}$ were detected in the range $51.59-1323.68 \mathrm{mg} / \mathrm{kg}$ and $23.55-204.52 \mathrm{mg} / \mathrm{kg}$, respectively. Cadmium in the concentration of $8.03 \mathrm{mg} / \mathrm{kg}$ was found at only one site in Abare (AB 11).

The permissible level of $\mathrm{Pb}$ in soil of residential areas in the US is $400 \mathrm{mg} / \mathrm{kg}[16,17]$. This value is exceeded in a home in Dareta (DA 01) and grinding sites in Dareta (DA 06-09), and is probably due to the volume of ore being processed over time. The concentration values for $\mathrm{Pb}, \mathrm{Cu}$ and $\mathrm{Cd}$ are comparable for the residential grinding sites DA 01-05 and DA 07-10 in Dareta and AB 06-10 (36.16-1615.79 mg/kg) in Abare. DA 06 appears to be an isolated case. It is pertinent to note that even though there is no mine in Abare, the inhabitants of the two villages appear to be processing about similar quantities of ores. With the exception of site $\mathrm{DA} 13$, the levels of $\mathrm{Pb}$ at the mining sites in Dareta (DA 11-15) exceeded the USEPA limit. It should be noted that the site DA 14 is located at the entrance of the main mining site. The mining activities have severely polluted this site and are responsible for the very high level of $\mathrm{Pb}$ observed in $\mathrm{DA} 14(3760.96 \mathrm{mg} / \mathrm{kg})$. In the pond environment in Abare ( $A B$ 01-05), the Pb levels in the soil were very high, with $4051.76 \mathrm{mg} / \mathrm{kg}$ and $3720.62 \mathrm{mg} / \mathrm{kg}$ detected at sites $A B 02$ and $A B$ 04, respectively. This may be due to the gathering of processors at these sites. The levels of $\mathrm{Pb}$ were moderately high at $A B 01$ and $A B 03$ showing values of $900.40 \mathrm{mg} / \mathrm{kg}$ and $606.14 \mathrm{mg} / \mathrm{kg}$, respectively. At powdered ore washing sites in Abare ( $A B$ 11-15), high levels of $P b$ were found at $A B 12(1323.68 \mathrm{mg} / \mathrm{kg})$ and $A B 15(51.586 \mathrm{mg} / \mathrm{kg})$. It is significant that these values were recorded in Abare where there are no mines. However, the stream and pond in Abare are both used by the two communities for the washing of the ores. The high concentration value of $\mathrm{Pb}$ found at $\mathrm{AB} 15$ maybe due to several processors who converge at this site.

The permissible limit for $\mathrm{Cu}$ in the soil of residential areas is $190 \mathrm{mg} / \mathrm{kg}$ [18]. Data in Table 1 show that $\mathrm{Cu}$ levels in the soil samples from Dareta were under the permissible limit except for DA 14 located at the mining site, where $213.8 \mathrm{mg} / \mathrm{kg}$ was detected. In Abare, this permissible limit was highly exceeded at pond sites ( $A B 02$ and $A B$ 04) with the values of 458.37 and $584.60 \mathrm{mg} / \mathrm{kg}$, respectively and marginally exceeded in the residential processing site ( $A B$ 12) where $204.52 \mathrm{mg} / \mathrm{kg}$ of $\mathrm{Cu}$ was detected.

The permissible limit of $\mathrm{Cd}$ in the soil is $12 \mathrm{mg} / \mathrm{kg}$ [18]. Cadmium was not detected in soil samples taken from the residences in Dareta (DA 01-10), but two sites in the mining areas (DA 11 and DA 14) showed Cd levels of 804 and $1354 \mathrm{mg} / \mathrm{kg}$, respectively. These concentrations of Cd were 67 and 113 times higher than the permissible limit. Cadmium was also detected at two locations in Abare ( $A B \quad 04$ and $A B$ 11). High level of $1216.25 \mathrm{mg} / \mathrm{kg}$ found in $A B 04$ is 101 times higher than the permissible limit, while the level of $C d$ in $A B 11$ is under the limit. It is pertinent to note here that all sites where $C d$ was detected (DA 11, DA 14 and $A B$ 04), exhibited high levels of $\mathrm{Pb}$ too.

In summarizing the results given in Table 1, it can be said that more than $50 \%$ of the soil samples collected from Dareta and Abare were contaminated by $\mathrm{Pb}, 20 \%$ by $\mathrm{Cu}$ and $12 \%$ by $\mathrm{Cd}$. This is in agreement with the Joint United Nations Environment Programme-Office for the Coordination of Human Affairs (UNEP/OCHA) Environmental Unit (JEU) report [19] on lead pollution and poisoning crisis in Zamfara State. This report showed that the top soil collected from various locations in Dareta and Abare were heavily polluted by $\mathrm{Pb}$. At a processing site near a mosque in Abare, the $\mathrm{Pb}$ level in the soil was reported as $1210 \mathrm{mg} / \mathrm{kg}$, while for the top soil from a near site close to a private well, the $\mathrm{Pb}$ level of $27000 \mathrm{mg} / \mathrm{kg}$ was reported. The UNEP/OCHA study has also reported Pb levels 
of $23600 \mathrm{mg} / \mathrm{kg}$ in top soil from a grinding site in Abare and $37500 \mathrm{mg} / \mathrm{kg}$ in top soil from a processing site near a well in Dareta [19]. However, the UNEP/OCHA study did not report any pollution of the soil by $\mathrm{Cu}$ and/or $\mathrm{Cd}$.

A study on the assessment of lead, mercury and arsenic levels in soils of Dareta, Bagega, Sunke, Abare and Yargalma villages in North-Western Nigeria was reported in 2014 [20]. Lead concentrations in soil samples were found to be in the range of $6.91-4157 \mathrm{mg} / \mathrm{kg}$. The average concentration of $\mathrm{Pb}$ in farmlands in Abare was reported to be $515 \mathrm{mg} / \mathrm{kg}$ [21].

The results of all these studies, as well as those presented in this report show that top soil in several parts of Abare and Dareta residences are heavily polluted by $\mathrm{Pb}$ as a result of mining activities. In a household survey carried out by Blacksmith Institute, 2011 in two villages, Dareta and Yargalma in Anka area, it was reported that $66 \%$ of the population in the villages undertook at least one mining activity within their residences [22]. These mining activities include crushing of the ore, grinding, washing, drying, extracting gold with mercury and/or melting gold. The results of the study show the impact of anthropogenic activities on abundance of potentially harmful elements in the soils of the area. The mining activities exposed the women and children to high levels of $\mathrm{Pb}$ in the soil and this may be responsible for the mean blood lead concentration of $119 \mu \mathrm{g} / \mathrm{dL}$ found in children from these villages. Blood levels as low as $10 \mu \mathrm{g} / \mathrm{dL}$ are associated with impaired neurological development in young children [23].

In the present paper, the levels of $\mathrm{Cu}$ were generally found under the limit at most of the sites. However, prolonged exposure to these metals could lead to bioaccumulation. Some of the most commonly reported adverse health effects of $\mathrm{Cu}$ are gastrointestinal distress, nausea, vomiting, abdominal pain irritation of the respiratory tract, coughing, sneezing and pulmonary fibrosis [24]. The levels of Cd found at two sites in Dareta (DA 11 and DA 14) and one site in Abare (AB 04) are excessively high and pose a health risk to the processors in these sites. The kidney is the main organ affected by the chronic $\mathrm{Cd}$ exposure and toxicity. Cadmium accumulates in the kidney which may result in renal failure [25].

In a study carried out in 2014, on discharges of potentially harmful elements (PHEs) in soils from various sites in Anka Local Government Area where artisanal mining for gold was carried out, concentrations of $\mathrm{Pb}$ equal to 2637, 1960, 3920, 290 and $3326 \mathrm{mg} / \mathrm{kg}$ were reported for mine site, ore processing site and village square, respectively [26]. The corresponding values for $\mathrm{Cu}$ at the same places were reported as 159, 159, 117, 29 and $223 \mathrm{mg} / \mathrm{kg}$, while the corresponding values for $\mathrm{Cd}$ were reported as $4.5,8.7,3.6,0$ and $6.9 \mathrm{mg} / \mathrm{kg}$.

In our study, the corresponding values for $\mathrm{Pb}$ shown in Table 1 for the mining sites (DA 11-DA 15) and residential processing sites (DA 01-DA 10 and AB 06-AB 10) ranged between 167-3761 and 19-1615 mg/kg, respectively. Here, the highest value of $26088 \mathrm{mg} / \mathrm{kg}$ was observed at only one location (DA 06). The corresponding values for Cu ranged between 49-214 mg/kg at the mining sites and between 3-49 $\mathrm{mg} / \mathrm{kg}$ for the residential sites, respectively. It should be noted that $79 \mathrm{mg} / \mathrm{kg}$ of $\mathrm{Cu}$ was detected at DA 06. The corresponding values for Cd ranged between 0-1354 $\mathrm{mg} / \mathrm{kg}$ and are detected at the mining sites only.

It must be noted here that the values of $\mathrm{Pb}$ in the mine and processing sites in two studies are comparable, except for the high value of 26,088 detected at DA 06 . Also, the values for $\mathrm{Cu}$ in the mine sites in the two studies are not far apart, but the values for the processing site in our study are significantly lower than those reported in 2014 [26]. The values for $\mathrm{Cd}$ for some mine sites in our study are significantly higher, while those for $\mathrm{Cu}$ are lower than the values reported in 2014 [26]. However, no GPS values were provided in the study carried out in 2014 [26]. 


\section{Plants/food analysis}

Concentrations of metals in the samples of plants and food presented in Table II show that concentrations of $\mathrm{Pb}$ in the cereals; guinea corn, maize and millet seeds from Abare were in the range of $5.70-24.56 \mathrm{mg} / \mathrm{kg}$. The value for beans was $10.64 \mathrm{mg} / \mathrm{kg}$, while the value for the elephant grass was $24.63 \mathrm{mg} / \mathrm{kg}$. In Dareta, the values of $\mathrm{Pb}$ in guinea corn and millet seeds were 79.91 and $22.29 \mathrm{mg} / \mathrm{kg}$, while the corresponding values found in guinea corn and millet leaves were 36.86 and $22.76 \mathrm{mg} / \mathrm{kg}$, respectively. The concentrations of $\mathrm{Cu}$ in the cereals in Abare were in the range of $11.17-14.84 \mathrm{mg} / \mathrm{kg}$, while the corresponding value for beans was $30.41 \mathrm{mg} / \mathrm{kg}$ and the value for elephant grass was $27.37 \mathrm{mg} / \mathrm{kg}$. In Dareta, the values of copper in guinea corn and millet seeds were $41.21 \mathrm{mg} / \mathrm{kg}$ and $11.53 \mathrm{mg} / \mathrm{kg}$, respectively, while the levels of $\mathrm{Cu}$ in guinea corn leaves and millet leaves were 19.05 and $40.58 \mathrm{mg} / \mathrm{kg}$ respectively. Cadmium was not detected in guinea corn, millet, beans and elephant grass in Abare, but the maize from Abare was found to contain $5.74 \mathrm{mg} / \mathrm{kg}$ of $\mathrm{Cd}$. In Dareta, $\mathrm{Cd}$ was not detected in the cereals, but the level found in millet leaves was $5.34 \mathrm{mg} / \mathrm{kg}$.

Guinea corn, maize and millet are the main food in this sub region, and therefore the concentrations of heavy metals in the food samples grown in the contaminated soils are pertinent to health. It is shown in Table II that the levels of $\mathrm{Pb}$ in guinea corn and millet seeds in Abare were 15.60 and $7.50 \mathrm{mg} / \mathrm{kg}$, respectively, while the corresponding values for these samples in Dareta were $79.91 \mathrm{mg} / \mathrm{kg}$ and $22.29 \mathrm{mg} / \mathrm{kg}$, respectively. The values for Dareta samples were understandably higher than the values for Abare samples because the tonnage of gold ore processed in Dareta is much higher than that of Abare. The permissible limit of $\mathrm{Pb}$ in cereals is $0.1 \mathrm{mg} / \mathrm{kg}$ [27]. This value is highly exceeded by factors in the range 156-799 for guinea corn seeds and 57-223 for millet seeds. The level of $\mathrm{Pb}$ in the maize sample from Abare exceeds the permissible level by a factor of 245 . The corresponding factor in beans is 106 . Thus, all the cereals in Abare and Dareta are not good for human consumption because of the high level of $\mathrm{Pb}$. Elephant grass, guinea corn leaves and millet leaves that are consumed by cattle also showed very high levels of Pb. Thus, $\mathrm{Pb}$ can enter the food chain and will be transferred to humans who consume meat from such cattle. The permissible limit for $\mathrm{Cu}$ in cereals is $2 \mathrm{mg} / \mathrm{kg}$ [27]. The value for millet seeds was $14.84 \mathrm{mg} / \mathrm{kg}$ and $11.17 \mathrm{mg} / \mathrm{kg}$ in guinea corn seeds in Abare while in Dareta, the value for millet seeds was $11.53 \mathrm{mg} / \mathrm{kg}$ and that for guinea corn seeds was $41.21 \mathrm{mg} / \mathrm{kg}$. The values for millet seeds in Abare and Dareta were comparable but the value for guinea corn seeds in Dareta of $41.21 \mathrm{mg} / \mathrm{kg}$, is more than double the values for guinea corn and millet seeds in Abare and the millet seeds in Dareta. The value of $30.41 \mathrm{mg} / \mathrm{kg}$ for beans obtained in Dareta was also much higher than those for the other food items except for guinea corn seeds. The values for the elephant grass in Abare and the guinea corn and millet leaves from Dareta also exceeded the permissible level by factors ranging from 10-20, if the permissible value of $2 \mathrm{mg} / \mathrm{kg}$ for cereal is adopted. Cadmium was detected in the maize from Abare and millet leaves in Dareta, and both values exceeded the permissible limit of $0.1 \mathrm{mg} / \mathrm{kg}$ for $\mathrm{Cd}$ by a factor of about 50 .

According to data in Table 2, it seems that all the plant samples were polluted by $\mathrm{Pb}$ and $\mathrm{Cu}$, while maize in Abare and millet leaves in Dareta were found to contain Cd as a third contaminant. The samples that were collected from the field, namely elephant grass, guinea corn leaves and millet leaves had $\mathrm{Pb}$ values in the range $22.76-36.86 \mathrm{mg} / \mathrm{kg}$, while the food items purchased from homes with the exception of guinea corn from Dareta had $\mathrm{Pb}$ values in the range $5.70-24.56 \mathrm{mg} / \mathrm{kg}$. The plants obtained from the fields would be contaminated by dusts from ore-processing. It should also be borne in mind that items kept in the residences could also be contaminated by dusts from ore- 
processing activities in the residential areas. This is probably responsible for the value of $79.91 \mathrm{mg} / \mathrm{kg}$ for $\mathrm{Pb}$ and $41.21 \mathrm{mg} / \mathrm{kg}$ for $\mathrm{Cu}$ in guinea corn seeds obtained from Dareta.

The possible sources of heavy metal contamination of the food samples are: direct contact with the ores, uptake from polluted soils, uptake from metal-polluted air, deposition on the surface of plants and exposed food items and contact with polluted water used for irrigation. All these are potential sources of contamination in Abare and Dareta. However, irrigation was not observed in Dareta. Crops and vegetables grown in soils contaminated with heavy metals have been reported to accumulate higher levels of heavy metals than those grown in uncontaminated soils $[28,29]$.

The consumption of the contaminated cereals, millet, guinea corn and maize seeds as well as beans by the inhabitants of Dareta and Abare will pose a risk to human health. The elephant grass obtained from Dareta with mean Pb concentration of $24.63 \mathrm{mg} / \mathrm{kg}$ is also unsafe for the livestock.

In a study carried out on the human health risk characterization of lead pollution in plants harvested from contaminated farmlands of Abare village, $\mathrm{Pb}$ concentration of sorghum exceeded the FAO/WHO limit by a factor of 3500 [21]. The time of sampling, however, was not stated.

One of the most widely studied mechanisms of action of toxic metals is oxidative damage due to direct generation of free radical species and depletion of antioxidant reserves [30]. Mercury, cadmium and lead can effectively inhibit glutathione peroxidase thereby reducing the effectiveness of this antioxidant defense system for detoxification [31]. Some heavy metals act as molecular mimics of nutritionally essential trace elements and compete with metallic cofactors for entry into cells and incorporation into enzymes [32]. Cadmium can compete with and displace zinc from proteins while lead and thallium are chemically similar to calcium and potassium [32-34].

Lead toxicity in human adults can lead to poor muscle coordination, nerve damage to the sense organs and nerves controlling the body, increased blood pressure, hearing and vision impairment and decreased sperm count. In children it can lead to damage to the brain, nervous system, liver, kidney and death [35]. Children less than seven years old are largely at risk [16].

The health implication of the results presented in this study is the possible occurrence of $\mathrm{Pb}, \mathrm{Cu}$ and $\mathrm{Cd}$ poisoning in all the people exposed to the ores. Ores are processed in residential areas by women and older children. Children including infants sometimes put unwashed hands in their mouths thus ingesting the ore dust. They also inhale the dust during processing of the ore. They have less tolerance to heavy metal toxicity and hence high mortality of exposed children is inevitable. The women are equally exposed and mortality though not as high as in children, would be expected. All the inhabitants ingest the contaminated foods and thus would be victims of heavy metal toxicity, namely lead and cadmium. Lead toxicity is implicated in abdominal pain, confusion, anemia, seizures, coma and deaths [36] while cadmium toxicity is implicated in lung cancer, kidney and bone damage [37].

All reports on high mortality in Zamfara State have attributed the deaths to the $\mathrm{Pb}$ poisoning [38]. The electrochemical method used in this study has made it possible to establish the presence of other heavy metal pollutants, namely copper and cadmium which may also be implicated in the high mortality.

\section{Conclusions}

Linear sweep anodic stripping voltammetry has been found very useful in the identification and determination of heavy metal pollutants, copper, cadmium and lead in the soil and plants/food samples. Presence of very high concentrations of these metals in the samples from several parts of Abare and Dareta regions reported in this study is related to the mining of ores at these locations 
and may be implicated in the high mortality in Zamfara State. It is obvious that to address this health risk, safe mining practices should be enforced and soil remediation of all these areas should be carried out. Educating the people, especially children, on toxicity of heavy metals and monitoring of these toxic metals in their blood should also be carried out periodically.

\section{References}

[1] MedecinsSansFrontieres. MSF Briefing Paper, (2012) http://www.msf.org/en/article/lead-poisoningcrisis-zamfara-state-northern-nigeria (Accessed on $8^{\text {th }}$ October, 2017).

[2] W. O. Okiei, M. Ogunlesi, A. Adio, M. Oluboyo, International Journal of Electrochemical Science 11 (2016) 8280-8294.

[3] S. Khan, Q. Cao, Y. M. Zheng, Y. Z. Huang, Y.G. Zhu, Environmental Pollution 152 (2008) 686-692.

[4] E. D. Doe, A. K. Awua, O. K. Gyamfi, N. O. Bentil, American Journal of Applied Chemistry 1 (2013) 1721.

[5] W. J. O. Oti, International Journal of Environmental Science and Toxicology Research 3 (2) (2015) 1621.

[6] S. O. Salihu, J.O . Jacob, M. T. Kolo, Pakistan Journal of Nutrition 13 (2014) 722-727.

[7] W.A. Tegegne, Ethiopia Journal of Cereals and Oilseeds 6 (2015) 8-13.

[8] E. J. Martinez-Finley, S. Chakraborty, S. Fretham, M. Aschner, Metallomics 4 (2012) 593-605.

[9] A. T. Jan, M. Azam, K. Siddiqui, A. Ali, I. Choi, Q. M. R. Haq, International Journal of Molecular Sciences 16 (2015) 29592-29630.

[10] D. A. Cataldo, R. E. Wildung, Environmental Health Perspectives 27 (1978) 149-159.

[11] M. C. Jung, Sensors 8 (2008) 2413-2423.

[12] B. V. Tangahu, S. R. S. Abdullah, H. Basri, M. Idris, N. Anuar, M. Mukhlisin, International Journal of Chemical Engineering 2011 (2011) 1-31.

[13] M. A. Adegboye, Journal of Science and Environmental Management 3 (2013) 77-83.

[14] Z. Y. Hseu, Bioresource Technology 95 (2014) 53-59.

[15] P. Chooto, P. Wararatananurak, C. Innuphat, ScienceAsia 36 (2010) 150-156.

[16] US EPA. United States Environmental Protection Agency. 40 CFR Part 745 [OPPTS-62156H; FRL-67635] RIN 2070-AC63. Lead; identification of dangerous Levels of Lead: Final Rule, 2001

[17] US EPA. Supplemental guidance for developing soil screening levels for superfund sites. Office of Solid Waste and Emergency Response, Washington, D.C. (2002) http://www.epa.gov/superfund/health/conmedia/soil/index.htm (Accessed on $8^{\text {th }}$ October, 2017).

[18] WHO. Permissible limits of heavy metals in soil and plants, (Genava: World Health Organization), Switzerland (1996).

[19] UNEP/OCHA, Joint UNEP/OCHA Environment Unit. Lead Pollution and Poisoning Crisis Environmental Emergency Response Mission Zamfara State, Nigeria (2010).

[20] K. D. Tsuwang, I. O. Ajigo, U. A. Lar, International Journal of Science and Environmental Technology 3 (2014) 187-197.

[21] A. Abdul, A. A. Yusuf, African Journal of Environmental Science and Technology 7 (2013) 911-916.

[22] Blacksmith Institute. UNICEF Programme. Environmental Remediation - Lead Poisoning in Zamfara State FINAL REPORT, September 2010-March 2011.

[23] CDC. Centre for Disease Control and Prevention. New lead information. National Center for Environmental Health. Division of Emergency and Environmental Health Services, 2017.

[24] ATSDR, Agency for Toxic Substances and Disease Registry. Toxicological profile for copper. U.S. Department of Health and Human Services Public Health Service, 2004.

http://www.atsdr.cdc.gov/toxprofiles/tp132.pdf (Accessed on $8^{\text {th }}$ October, 2017).

[25] N. Johri, G. Jacquillet, R. Unwin, Biometals 23 (2010) 783-792.

[26] L. Uriah, C. T. Ngozi-Chika, K. Tsuwang, American Journal of Environmental Protection 3(6-2) (2014) 14-18.

[27] FAO/WHO. Joint FAO/WHO Food Standards Programme. Codex Alimentarius Commission. Report of the fifth Session of the Codex Committee on Contaminants in Foods.Thirty-fourth Session, Geneva, Switzerland, 2011, www. ftp://ftp.fao.org/codex/meetings/CCCF/cccf5/cf05 INF.pdf (Accessed on $8^{\text {th }}$ October, 2017). 
[28] G. Guttormsen, B. R. Singh, A. S. Jeng, Fertilizer Research 41 (1995) 27-32.

[29] C. K. Bempah, A. B. Kwofie, A. O. Tutu, D. Denutsui, N. Bentil, Elixir International Journal 39 (2011) 4921-4926.

[30] N. Ercal, H. Gurer-Orhan, N. Aykin-Burns, Current Topics in Medicinal Chemistry 1 (2001) 529-539.

[31] C. C. Reddy, R. W. Scholz, E. J.Massaro, Toxicology and Applied Pharmacology 61 (1981) 460-468.

[32] D. H. Jang, R.S. Hoffman, Neurologic Clinics 29 (2011) 607-622.

[33] G. W. Buchko, N. J. Hess, M. A. Kennedy, Carcinogenesis 21 (2000) 1051-1057.

[34] F. Thevenod, W.K. Lee, Metal lons in Life Sciences 11 (2013) 415-490.

[35] ATSDR, Agency for Toxic Substances and Disease Registry. Toxicological profile for lead. Division of Toxicology and Environmental Medicine, Atlanta, GA, 2007.

http://www.atsdr.cdc.gov/toxprofiles/tp13-p.pdf (Accessed on $8^{\text {th }}$ October, 2017).

[36] ATSDR. Agency for Toxic Substances and Disease Registry. Case studies in environmental medicine (CSEM). Lead toxicity. Course WB 1105. Atlanta GA, 2010.

[37] ATSDR. Agency for Toxic Substances and Disease Registry. Toxicological profile for cadmium, US Department of Health and Human Services, Atlanta, GA. 2012, pp 1-487.

[38] WHO. World health Organization. Nigeria: Mass lead poisoning from mining activities, Zamfara State, 2010. http://www.who.int/csr/don/2010 07 07/en/ (Accessed on $8^{\text {th }}$ October, 2017).

(C2017 by the authors; licensee IAPC, Zagreb, Croatia. This article is an open-access article distributed under the terms and conditions of the Creative Commons Attribution license (http://creativecommons.org/licenses/by/4.0/) 